\title{
Online Validation of Mortgage Backed Security System for Easiness of Customers
}

\author{
C. Archanapriya, S. Mari, N. Mathankumar
}

\begin{abstract}
A home loan bond is a bond upheld by a pool of home loans on a land resource, for example, a house. All the more for the most part, bonds which are verified by the promise of explicit resources are called home loan bonds. Home loan bonds can pay enthusiasm for either month to month, quarterly or semi yearly periods. The commonness of home loan bonds is generally credited to Mike Vranos.These securitization trusts might be organized by government-supported undertakings just as by private substances that may offer credit improvement highlights to alleviate the danger of prepayment and default related with these home loans. Since private home loan holders in the United States have the choice to pay more than the necessary regularly scheduled installment (diminishing) or to satisfy the advance completely (prepayment), the month to month income of a MBS isn't known ahead of time, and a MBS thusly introduces a hazard to financial specialists.
\end{abstract}

Keywords: securitization, Mike Vranos

\section{INTRODUCTION}

A home advance supported security (MBS) is a kind of advantage upheld securitythat is checked by a mortgageor social occasion of home advances. The home advances are offered to a social affair of individuals (an organization office or hypothesis bank) that securitizes, or packages, the credits together into a security that money related masters can buy. The home advances of a MBS may be residentialor business depending upon whether it is an Agency MBS or a Non-Agency MBS; in the United States they may be surrendered by structures set by government-bolstered attempts like Fannie Mae or Freddie Mac, or they can be "private-mark", surrendered by structures set by adventure banks. The structure of the MBS may be known as "experience", where the interest and head portions from the borrower or homebuyer experience it to the MBS holder, or it may be progressively astounding, made up of a pool of various MBSs. Various types of MBS fuse collateralized contract responsibilities (CMOs, consistently sorted out as land contract hypothesis courses) and collateralized commitment duties (CDOs).[1]-[4]

Revised Manuscript Received on December 30, 2019.

C. Archanapriya, Assistant Professor, Department of Science \& Humanities,Bharath Institution Of Higher Education And Research TamilNadu, India Email: Archanapriya854@gmail.com

S. Mari, Assistant Professor, Department of Science \& Humanities,Bharath Institution Of Higher Education And Research TamilNadu, India Email maripalani09@gmail.com

N. Mathankumar Assistant Professor, Department of Science \& Humanities,Bharath Institution Of Higher Education And Research TamilNadu, India Email ma.aswinkumar18@gmail.com
A home loan bond is a bond upheld by a pool of home loans on a land resource, for example, a house. All the more for the most part, bonds which are verified by the promise of explicit resources are called home loan bonds. Home loan bonds can pay enthusiasm for either month to month, quarterly or semi yearly periods. The commonness of home loan bonds is generally credited to Mike Vranos.

\section{SECURITIZATION}

The procedure of securitization complex and depends incredibly on the purview inside which the procedure is led. In addition to other things, securitization appropriates hazard and allows speculators to pick various degrees of venture and hazard the essentials are: [5]-[8]

1. Mortgage advances (contract notes) are acquired from banks and different moneylenders, and perhaps doled out to a unique reason vehicle (SPV).

2. The buyer or trustee amasses these credits into accumulations, or "pools".

3. The buyer or trustee securitizes the pools by giving mortgagebacked protections.

While a private home loan supported security (RMBS) is verified by single-family or two-to four-family land, a business contract upheld security (CMBS) is verified by business and multi-family properties, for example, condo structures, retail or office properties, inns, schools, modern properties, and other business locales. A CMBS is normally organized as an alternate kind of security than a RMBS. [9]-[16] In the United States, the most widely recognized securitization trusts are supported by Fannie Mae and Freddie Mac, US government-supported ventures. Ginnie Mae, a US government-supported undertaking sponsored by the full confidence and credit of the US government, ensures that its speculators get convenient installments however purchases restricted quantities of home loan notes. Some private establishments likewise securitize contracts, known as "private-name" contract protections. Issuances of private-name contract sponsored protections expanded drastically from 2001 to 2007 and afterward finished unexpectedly in 2008, when land markets started to flounder. A case of a private-mark backer is the land contract venture channel (REMIC), a duty structure substance typically utilized for CMOs; in addition to other things, a REMICstructure maintains a strategic distance from alleged twofold tax collection[17]-[20]

Published By:

Blue Eyes Intelligence Engineering 


\section{RESULTS}

\section{A. FIXED-COUPON BONDS AND MORTGAGE BONDS}

There are various ways that home loan sponsored protections, for example, pass-throughs and CMOs, vary from increasingly conventional fixed-salary securities, for example, corporate and metropolitan securities. The graph underneath gives a correlation of a number key bond factors.

\begin{tabular}{|l|l|}
\hline Fixed-Coupon Bonds & Mortgage Bonds \\
\hline Semiannual coupon & Monthly coupon \\
\hline Coupon amount stays the same & Coupon amount vanies each month \\
\hline Couponime & \\
\hline Collect principal when bond \\
matures & Collect principalincrementally each month \\
\hline Concise maturity date & $\begin{array}{l}\text { Couponis interest and principal } \\
\text { will mature }\end{array}$ \\
\hline
\end{tabular}

B. INTERPRETATION ON US MORTGAGE BACKED SECURITY

\begin{tabular}{|c|c|c|c|c|c|c|}
\hline Date & Price & Open & High & Low & Vol. & $\begin{array}{l}\text { Change } \\
\%\end{array}$ \\
\hline $\begin{array}{c}\text { 18- } \\
\text { Mar }\end{array}$ & 4.967 & 4.986 & 4.986 & 4.967 & 0 & 0.04 \\
\hline $18-\mathrm{Feb}$ & 4.965 & 4.986 & 4.993 & 4.956 & $21.17 \mathrm{~K}$ & -0.8 \\
\hline $18-\mathrm{Jan}$ & 5.005 & 5.063 & 5.072 & 5.005 & $0.93 \mathrm{~K}$ & -1.13 \\
\hline 17-Dec & 5.062 & 5.055 & 5.077 & 5.043 & $14.82 \mathrm{~K}$ & 0.08 \\
\hline $17-$ Nov & 5.058 & 5.064 & 5.075 & 5.054 & $19.72 \mathrm{~K}$ & -0.12 \\
\hline 17-Oct & 5.064 & 5.077 & 5.079 & 5.055 & $104.19 \mathrm{~K}$ & -0.16 \\
\hline $17-$ Sep & 5.072 & 5.08 & 5.088 & 5.076 & $3.56 \mathrm{~K}$ & -0.2 \\
\hline $\begin{array}{l}\text { 17- } \\
\text { Aug }\end{array}$ & 5.082 & 5.059 & 5.075 & 5.059 & $0.05 \mathrm{~K}$ & 0.67 \\
\hline 17-Jul & 5.048 & 5.025 & 5.05 & 5.014 & $16.35 \mathrm{~K}$ & 0.42 \\
\hline 17-Jun & 5.027 & 5.035 & 5.035 & 5.034 & $100.00 \mathrm{~K}$ & -0.26 \\
\hline
\end{tabular}

\section{INTERPRETATION:}

The prices are very high from July 17 to December 17.so the investors Can sell the securities during that period After. December 2017 till March 18 the prices are constantly decreasing so the investors can buy the security[21]-[24]

\section{CONCLUSION}

At the point when one contribute inMBS(mortgage upheld security) they are essentially loaning cash to a home buyer or business MBS is a route for a little bank to propel home loans to it's customers without stressing over the benefits they need to ensure the credit as the bank go about as a promptly between the home shopper and the hypothesis showcase MBS exchanged by the administration offices are transcendently appealing in light of the fact that the arrival are sure by these offices, which are themselves bolstered by the central government.

\section{REFERENCES}

1. Vasanthi, S. \& Rabiyathul Basariya, S. 2019, "Influence of value analysis and cross training in industry", International Journal of Engineering and Advanced Technology, vol. 8, no. 6, pp. 1810-1811.

2. Velvizhi, R., Sri Gowtham, S. \& Jeya Priya, D. 2019, "Examination of early feedbacks for effective product retailing on E-commerce websites", International Journal of Engineering and Advanced Technology, vol. 8, no. 6 Special Issue 2, pp. 703-706.

3. Anuradha, C., Pothumani, S. \& Kavitha, R. 2019, "A novel method towards E-commerce", International Journal of Engineering and Advanced Technology, vol. 8, no. 6 Special Issue 2, pp. 535-538.

4. Thomas, J. \& Rabiyathul Basariya, S. 2019, "A study on the issues of financial ratio analysis", Indian Journal of Public Health Research and Development, vol. 10, no. 3, pp. 1079-1081.

5. Ramachandran, S. \& Rabiyathul Basariya, S. 2019, "Online marketing - study on customer satisfaction and relationship", Indian Journal of Public Health Research and Development, vol. 10, no. 3, pp. 1072-1078.

6. Priya, R., Vinothini, G. \& Cor Jesu, C.D. 2019, "The mentor-protégé relationship for professional growth", Journal of Advanced Research in Dynamical and Control Systems, vol. 11, no. 9 Special Issue, pp. 1110-1119.

7. Jannifer Rani, N., Bina Pani, S. \& Nimisha, N.S. 2019, "A study on money back polices available in LIC", Journal of Advanced Research in Dynamical and Control Systems, vol. 11, no. 9 Special Issue, pp. 833-839.

8. Saillaja, V., Jhansi Rani, K. \& Catherine, R. 2019, "Global marketing management planning and organization", Journal of Advanced Research in Dynamical and Control Systems, vol. 11, no. 9 Special Issue, pp. 489-493

9. Saillaja, V., Jhansi Rani, K. \& Catherine, R. 2019, "The new phase of marketing information system", Journal of Advanced Research in Dynamical and Control Systems, vol. 11, no. 9 Special Issue, pp. 482-488.

10. Thoufiqulla \& Raju, D.V. 2019, "Perception of indian investor towards investment in mutual funds with special reference to mip funds", Journal of Advanced Research in Dynamical and Control Systems, vol. 11, no. 5, pp. 177-183.

11. Jasmine, K.R.M. \& Basariya, S.R. 2018, "A study on the customers benefits on mutual funds", International Journal of Civil Engineering and Technology, vol. 9, no. 4, pp. 45-48.

12. Vasanthi, S. \& Basariya, S.R. 2019, "Pros and cons of on the job training versus off the job training", International Journal of Scientific and Technology Research, vol. 8, no. 10, pp. 671-674

13. Pavithra, J. \& Ganesan, M. 2016, "A study on awareness and impact of micro-financial schemes", International Journal of Applied Business and Economic Research, vol. 14, no. 8, pp. 5449-5460.

14. Pavithra, J., Dilli Babu, P. \& Ambuli, T.V. 2014, "A study on budgetary control at Maruti Service Masters, Chennai", International Journal of Applied Business and Economic Research, vol. 12, no. 2, pp. 151-161.

15. Gunaraja, T.M. \& Venkatrama Raju, D. 2018, "Determining factors of organisational climate with reference to leadership styles", International Journal of Mechanical Engineering and Technology, vol. 9, no. 9, pp. 1327-1332. 
16. Gunaraja, T.M. \& Venkatrama Raju, D. 2018, "The role of job satisfaction and training of employees in determining organisational climate of a selected industry", International Journal of Civil Engineering and Technology, vol. 9, no. 8, pp. 1266-1269.

17. Aarathy, T.S. \& Raju, D.V. 2018, "Performance appraisal and its effects on employees with respect to it sector in Chennai city", International Journal of Civil Engineering and Technology, vol. 9, no. 6, pp. 1535-1538.

18. Aarathy, T.S. \& Raju, D.V. 2018, "Employee perception towards performance appraisal system in IT sector", International Journal of Mechanical Engineering and Technology, vol. 9, no. 5, pp. 131-135.

19. Porselvi, W., Jublee, D. \& Sivanesan, G. 2018, "A study on factors influencing adoption of technology and innovation in banking industry, tamilnadu, India", International Journal of Mechanical Engineering and Technology, vol. 9, no. 5, pp. 789-800.

20. Akessa, G.M. and Dhufera, A.G., 2015. Factors That Influences Students Academic Performance: A Case of Rift Valley University, Jimma, Ethiopia. Journal of Education and Practice, 6(22), pp.55-63.

21. Miller, G. and Shih, C.C., 1999. A faculty assessment of the academic rigor of on-and off-campus courses in agriculture. Journal of Agricultural Education, 40, pp.57-65.

22. Tsinidou, M., Gerogiannis, V. and Fitsilis, P., 2010. Evaluation of the factors that determine quality in higher education: an empirical study. Quality Assurance in education, 18(3), pp.227-244.

23. Farooq, M.S., Chaudhry, A.H., Shafiq, M. and Berhanu, G., 2011. Factors affecting students' quality of academic performance: a case of secondary school level. Journal of quality and technology management, 7(2), pp.1-14.

24. Fitsilis, P., Gerogiannis, V. and Anthopoulos, L., 2014. Ontologies for software project management: a review. Journal of Software Engineering and Applications, 7(13), p.1096.

25. Adams, J.D. and Jaffe, A.B., 1996. Bounding the effects of R\&D: an investigation using matched establishment-firm data(No. w5544). National bureau of economic research.

\section{AUTHORS PROFILE}

C. Archanapriya, Assistant Professor, Department of Science \& Humanities,Bharath Institution Of Higher Education And Research TamilNadu, India

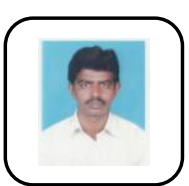

S. Mari, Assistant Professor, Department of Science \& Humanities,Bharath Institution Of Higher Education And Research TamilNadu, India

N. Mathankumar Assistant Professor, Department of Science \& Humanities,Bharath Institution Of Higher Education And Research TamilNadu, India 